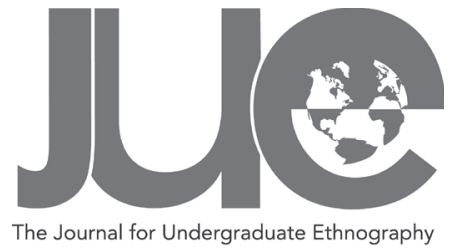

Volume 3 | Issue 1

\title{
Family in Foreign Spaces: Leaving Home to Find Home
}

\section{Hanna De Salvo}

Fort Lewis College, hdesalvo@fortlewis.edu

\section{ABSTRACT}

$\mathrm{n}$ the spring of 2012 I participated in an experiential education course. I taught

English and lived with a family in an economically poor and rural community situated

in Baja California, Mexico. During this process I began to explore how people in

different social realities experience place, nationalism, and identity. I was faced with my own privileges as a U.S. citizen as well as my socialized habits of individualism. This auto-ethnography combines my specific experience with larger social themes of national identity construction and the influence that stereotypes and national stories may have on social experiences.

Keywords: Auto-ethnography, Collectivism, Mexico, Domestic Space, National Identity 


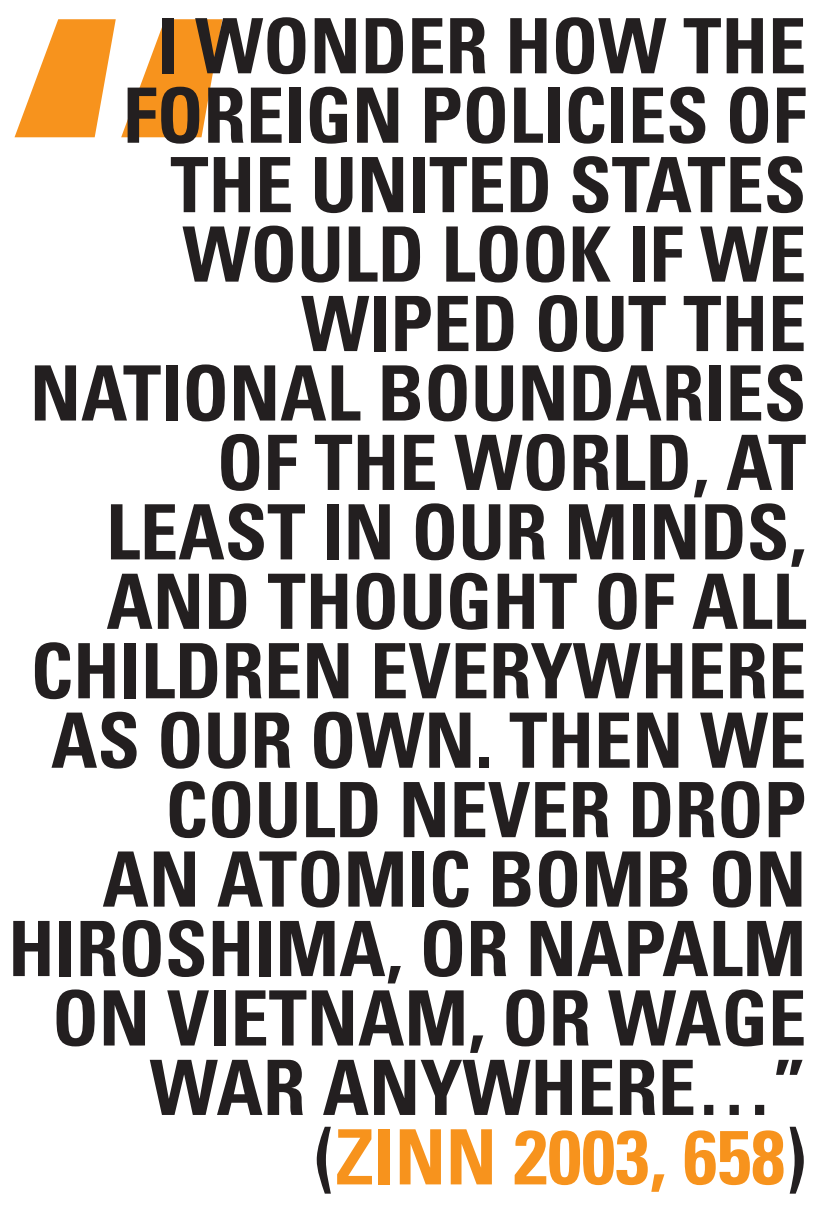




\section{INTRODUCTION}

Crossing the border into Mexico was among the strangest experiences of my life. Filled with both fear and anticipation, my classmates and I gathered at the border's wall and prepared to cross a bridge into a new country. We called our parents for the last time on our U.S. cell phones and smoked cigarettes while we observed the barrage of armed men patrolling the area. The uniforms and guns put me on edge and I began to second-guess my every move, wondering, "Am I breaking a law by standing here?" The presence of the U.S. police force seemed severe. Why is their presence so concentrated at that spot? Why had I not felt so uneasy in the streets of San Diego just minutes before?

As soon as we had neared the border and as we crossed the bridge, we stood out more and more; we are not from Mexico, we are "Americans". I felt different from the people around me and the realization that I was now the foreigner became clear. I realized that despite all of my knowledge surrounding the construction of race and politically enforced economic disparities, and though I intended to see the people in Mexico as inherently no different than me, I was petrified to be in such a foreign place. All the media depictions of people disappearing in foreign countries, of the drug wars in Mexico, of violence and crime as everyday occurrences, and all of my mother's warnings and questions about my safety, transformed from abstract thoughts to a concrete understanding of my experience to come. I could not deny that I would rather be safe than sorry, so I rationalized a newly-faced distrust of the nonwhite people that populate Mexico. I began to think, "What kind of person am I, really? Am I really full of hate? Where are these feelings coming from?"

My whole life had been spent adjusting to the society into which I was born to face and conditioned to navigate. Particularly, I had been coping with a culture that pretends our dying planet is a non-issue and that the lifestyles of even many poor Americans (U.S. citizens) comes at the cost of the well-being of communities, human and otherwise, that exist, to us, mostly as abstractions. Going to Mexico, a country whose misfortune has come at the behest of the economically wealthiest nation on the planet, hit me with a wave of realism and reconnection with the complexities of my life and its interconnection with all of the people of the world that I have never met. Almost all of my individualistic social behaviors, such as cooking, eating, sleeping, and studying alone, when and where I chose, were stripped during my stay in Mexico; yet I was simultaneously freed of the burden of individualism and

the isolation that it encourages. I noted at the culmination of my journey that "I'm more myself with the people in Buena Vista" than I have ever been.

Why was I so frightened to go to Mexico? It was important to understand why it seemed so engrained in me to fear Mexico and Mexican people despite my rationality. Why have I never experienced life outside of my white identity? Why are we taught to identify with one group of people and deny groups whom we do not actually know ourselves? I want to share why I felt such fear; how I was conditioned to feel in a way I knew was wrong. I want to ask people to really understand the sources of our alliances and enemies. Ultimately, I want to process the implications, for me and for all my future work, of having found family with such ease in a place I so feared. I found a home in a place I knew nothing about that was more comfortable than anything I have found in the places that I have lived thus far. I believe, based on my observations and on the history of U.S.-Mexico relations, that the racism, fear, and disdain I was enacting has been socially constructed in order to maintain the United States identity. Our privileges and sense of entitlement, which are mostly unnoticed and taken for granted by U.S. citizens, require us to identify with and participate in a culture that denies basic human rights and opportunities to the people just south of the border. Zinn captures this best in the following:

\begin{abstract}
I wonder how the foreign policies of the United States would look if we wiped out the national boundaries of the world, at least in our minds, and thought of all children everywhere as our own. Then we could never drop an atomic bomb on Hiroshima, or Napalm on Vietnam, or wage war anywhere... $(2003,685)$
\end{abstract}

This statement resonates strongly with my ultimate summation from my journey to Mexico: If we recognize that the people of Mexico, and all people whose "other" identities stand in juxtaposition to U.S. citizens' identity, are equal to us and a part of our family, our social, political and economic structure would not be possible. My research is an exploration of how national identity is formed and perpetuated through stereotypes. It is my goal to show the humanity and commonality of the people and physical 
spaces I was so hesitant to interact with by sharing my personal exploration of socially constructed divisions based on nationality, class, and cultural differences. I examine how the use of domestic space acculturates differences in social experience and perspective and how these differences are often used to create generalizations and stereotypes that keep people divided. Through my own journey I grew to become an integral part of communal family and social structure antithetical to all of my own previous experiences and the overarching individualistic and isolationist tendencies that I see here in the United States. Founded in the feminist standpoint theory, it is clear that my experiences are unique and exist because I stand at a particular intersection of race, class, nationality, and previous lived-experience, thus my reflection is limited.

This auto-ethnography is guided by my experience through the Mexico Bloc Program, provided by Fort Lewis College, in the spring of 2012. A Fort Lewis history professor named John Baranski led the program. He supported us through the experience and taught us two classes: "Movements of Resistance" and "U.S. Topics: Work and Immigration". Professors of Fort Lewis College have run this program for over twenty years. Academically, the program fills service-learning practicum requirements that make up the core of the sociology curriculum. Yet, the teachers that promote its continuance admit that it is unique and important for the ways that the students collectively confront their privileges, understand their particular experiences as educated U.S. citizens, and receive the guided opportunity of facing the stereotypes that are so normalized in our social reality. Students are urged to go regardless of their grasps of Spanish or English, the main requirements are character and perseverance. I was told in my interview with Baranski, months before our departure, "The more Spanish you know, the less you'll suffer."

In retrospect, I can admit that I signed up to participate in this program for a couple of reasons. One reason that I chose to go to Mexico was this urgent feeling that I had to leave Durango, CO and separate myself from the social aspects of North-American culture that were beginning to weigh heavily on my experience in life. Another cause for my participation was a desire to finish school. I foolishly thought that I would be able to cram two-semesters of college courses into this trip and come back to graduate. I was urged by previous participants that I could do no better for myself than to go on the Mexico trip, though the best reason that anyone could articulate was that, "it will change your life."

\section{"ONE REASON THAT I CHOSE TO GO TO MEXICO WAS THIS URGENT FEELING THAT I HAD TO LEAVE DURANGO, CO AND SEPARATE MYSELF FROM THE SOCIAL ASPECTS OF NORTH-AMERICAN CULTURE THAT WERE BEGINNING TO WEIGH HEAVILY ON MY EXPERIENCE IN LIFE." - DE SALVO}


The other Fort Lewis students and I converged in San Diego, CA and proceeded to travel together to the border at San Ysidro. Over the course of the month before the course began I traveled with my partner towards San Diego, CA, hitchhiking and ride-sharing. We caught a ride with a group of radical folks from Boulder all the way to San Francisco. We drove through the night in a caravan of two cars. We only first met these people when we got into their car to drive across the country. It is strange to me now how quickly we trusted this group of white 20-somethings who dressed and thought like us when I think about the fear I had for my life when I first entered Mexico. Racing across the desert at $3 \mathrm{am}$ I talked with the driver about the cause for our trek to the west, explaining, "I'm going to Mexico to teach English and live with a family." At this point I knew I would be in the smallest town in the valley, living on the beach and off the grid; I was going to live in a whole new world. They responded by saying, "That will change your life. You will never be the same." I shrugged it off and closed my eyes, thinking, "Yeah, it'll be great..." But I did not know then where I was going nor how many different borders I would cross to get to where I am today.

I spent three months living with a family and teaching English in a Telesegundaria, comparable to a U.S. middle school, in a town that I will be referring to as Buena Vista, which means "beautiful view" in Spanish. The majority of my data was collected through my participant observation as I got to know the people and the unique economy of Buena Vista. Because this is an autoethnography and because this experience has already happened, I am going to rely on my field-journal, my memory, and my subsequent reflections as my main methods of data collection. I explained that I was conducting research as a sociologist, trying to understand the lives of Mexican People, with the intention of using the data to compose a scholarly paper. To respect confidentiality, I am keeping the identities of the subjects and the places in my ethnography hidden. As the town is so small and family oriented, were any person to visit Buena Vista it would be no great task to piece together the identities of these people based on any information that I give.

Buena Vista is a small town consisting of nearly thirty homes. It is known as the "squatter's town" because it was, in fact, squatted by four families in the 1950's who simply moved to the beach and built four homes and a small school. The town is located on a peninsula that hugs a large bay, so it exists on a thin strip of land between a bay and the Pacific Ocean. The people in the town make their living harvesting the clams, mussels and seaweed that grow in the ocean. They have also introduced oysters into the bay that are collectively owned by the town and are another important source of income.

I gained access into this community because I was paying a family, whom I will refer to from hereon as my family, to house me. Filling a highly respected role as a teacher, and telling the people that this was my servicio social, or "required-for-college volunteer work", I was trusted from the outset and given access to formal and informal settings such as school-life and home-life.

I conducted my class at the school only 2-3 times a week, and had eight students. I attempted to teach English, with no background in teaching nor a firm background in the complexities of my "native" language. There were few resources and there were not enough English books for each student so I created my own materials: flash cards, bingo boards, and memory cards. Sometimes I would visit the school and observe, but the teacher was often not present and so school was frequently cancelled. Most of my time was spent in the private settings of my home, my host-uncle's home, and the home of an English-speaking friend that I made. Other settings for observation were the school, which was semiprivate, and stores/restaurants/hotels, which were semi-public because money was required to access them and, finally, at bus stops and on the streets around the valley, which were all public.

The town is now mostly populated by these initial squatter families; they have grown over the last sixty years and spread out across the beach in Buena Vista. I once asked my host-mother to estimate how many houses the town consisted of. In response she began counting the heads of each household and their relations to each other. She counted thirty-one. Her method of answering indicates to me a strong connection to place and exemplifies the ties between the people who inhabit this particular place. Here in Durango, I do not know my next-door neighbors by name nor the population of this city in which I live. Because of the small size and connectedness of the town, I was no stranger to the people. I walked to and from school every day along the one road and quickly made friends with different households that I ultimately visited often for coffee and conversation.

From the outset, I felt fraudulent for my lack of experience as a teacher and grasp of both languages involved. I felt I had no right to be welcomed into the community if I was not holding up my end of the deal. As time went on and I shared my fear of failing the students with many of the locals, however I was reassured with sentiments like, "we are proud to have you here," which my host mother told me repeatedly. It also became clear that the students 
I taught and the general community members were all facing the same opportunity as I was: to meet the people from the other side of the border that we tend to know only through stereotypical depictions seen in the media and passed through social networks. This realization that the connections we formed as people were more important than the words that my students or I could learn helped to give me a new perspective and more confidence as a person and thus, a teacher.

The family that I found in Buena Vista has always been there and they still are. They will likely never visit me here because of the long, arduous process and large amounts of money that are required to purchase a visa, let alone the tickets for transportation and cost of a vacation. The tears we all shed the day that I left were inspired by a deep connection that had formed over my threemonth stay, a connection that took time to forge. I did not know when I arrived what beauty and love I would come to know.

\section{HOME IS WHERE YOU ARE:}

\section{MY FIRST DAY IN BUENA VISTA}

I was the last to go to my town; I stayed a day more waiting to know where I would be for three months. The teacher that I worked with in the Telesegundaria picked me up at 7am and we drove for nearly an hour up a rocky, one-lane road along and around the bay to my town. The bay is vast and some say as large as the one in San Francisco. The drive was uncomfortable, mostly because communication was difficult. She said the only English word that she knew was "okay" and I could barely tell her about where I was from. As fear and doubt welled up within me, all the words I knew in Spanish were quickly forgotten. So I looked out the window and repeated, "Que bonita! Que hermosa es la tierra aqui?" This translates to, "How beautiful! How handsome the land is here!"

We stopped at a house standing alone, right off of the bay. A boy and his father were standing by the road. When we stopped, the boy jumped into the back seat and positioned himself around my bags. There was a sign so small I would have missed it had it not been pointed out to me; sitting beneath a tree, in hand painted letters, "Buena Vista" was displayed. A woman sat on the steps of the third house on the only road through town, which takes less than five minutes to drive through, and I knew I had arrived. She stood when she saw us pull in and as I opened the door two dogs came barking and would not let me out. The woman of the house gave them a stern yelling and they cowered away from me.
My first observations of the house revealed the strangest disparity that I could have imagined. There was, at once, no door to the house, only a doorway and a blanket held aside with a bungee cord, as well as a small solar panel atop the roof with a cord leading into the front window, which also had no pane. I thought it was a bit progressive to have a solar panel, a technology that, in the United States, is only available to a very small percentage of very wealthy people. After introducing me to my host-mother, the teacher reminded me to arrive at the schoolhouse at $10 \mathrm{am}$ to meet the eight students that I would be teaching, and then she drove off down the road.

My host-mother also knew the word "okay", but that was similarly the extent of her English vocabulary. She led me into the house. The front room is open to the kitchen and contained a very particular selection of furniture. There were two couches, covered with large blankets colored with Disney characters and horses. There was one candleholder on the wall but it hung upside-down on its nail. There was a calendar that displayed the wrong month and a very colorful picture of Jesus. There was an entertainment center that I would not notice until two days later. Strangest to me, at the time, was a hoard of flies buzzing about in the center of the dark, dank room, just out of the sun's rays that shone through the holes in the walls. I would learn to accept their presence, with time, at the heat of the day, and come to identify with their escape from the sweltering sun.

Through the living room was the kitchen. Only an archway in the wall separated the two rooms, as was the case throughout the house. The kitchen separated my room from the living room, barely. My room was windowless and dark at all times. There were names covering the walls in big letters to memorialize all the people who had lived in that room before. I came to know them all, throughout my time there. There were two queen-sized beds covered in blankets like those covering the couches. One would be both my bed and my bookshelf while the other was shared by both of my "sisters". The older girl would scarcely be present because she was attending the Prepatoria, the "high school" in the city in the valley, where I had just come from. I would be sharing my room with my fourteen-year old host-sister and student, whose language I did not speak. There was a dilapidated dresser covered with schoolbooks and perfumes and a large vanity mirror that the sun would grace for three or four hours each afternoon. Between that dresser and the corner farthest the doorway, was a pile of clothes half my height. 
To say the least, I was overwhelmed by the new home and the family I could not speak to. So, I took my sleeping bag out and, fully dressed, climbed in and took my first nap since middle school. My mother woke me with the news that class time was near and I must eat before I begin my teaching. She fed me caldo de pollo, or "chicken soup". On my last morning she fed me caldo de pollo again while she reminded me with tears in her eyes that that was the first meal we shared together. We ate together, mostly in silence. The meal was sprinkled with my attempts to express that I knew little Spanish. She told me not to be scared, that they were glad to have me there and after we ate she walked me to school.

The school is isolated from the rest of town, down a road that follows the beach. I arrived in time for my class to begin, but did not know until that moment that I was meant to teach on my first day. The nearest building is owned by a former U.S. citizen who became a Mexican citizen to prove to the people of Buena Vista that he was truly invested in the town and thus could be trusted to help organize the town's venture in abalone reintroduction. His house is the only building surrounded by a wall and the school is the only one surrounded by a ten-foot fence topped with barbed wire. The school was one room. There were four computers along the back wall but there was no electricity. I had eight students. My host-brother and my host-sister were two. One was my nextdoor neighbor and the son of my mother's sister. Another was the nephew of my host-siblings. Four of the eight students were in my family. Of the other four, two were brother and sister. On this first day they laughed at me as I told them I was unprepared. I wore tight, black, patched up pants; my face was riddled with piercings. We were very strange to each other at first.

\section{FACING THE BOUNDARIES OF AN INDIVIDUALIST}

On the first page of my field-journal I wrote the mission that Baranski assigned us: "Make the strange familiar and the familiar strange." There are no better words to describe what happened in the following three months.

"The culture of the U.S. is generally described as individualistic" (Shkodriania \& Gibbons 1997, 766) and Pader's (1993) research explores the ways that the spatial layout and the negotiations of domestic space influence the acculturation of behaviors, such as individualism or familism. One of "the most fundamental factors differentiating Mexican and Mexican American families from U.S. families" (Pader 1993, 117) is the cultures' respective emphasis on interdependence and independence.

Growing up, I always had my own room and my room was always a place I could go to be alone. This trend has continued throughout my life. In Mexican households, traditionally, infants sleep with their parents only until they are old enough to share beds and rooms with their siblings. In my Mexican home, my sisters shared a room and my brother slept with his parents or on the living room couch with his nephew, whose parents lived down the street and did not have a room for him. For me this extreme closeness was new and uncomfortable. Again and again my fieldjournal displays a want of privacy and a want of control over a space that is mine; "I just want to be alone," "Privacy is a great and powerful thing," "I have no privacy," "To have no privacy is infuriating at times." I felt it was my right to have privacy because I always had. Pader claims that "the lack of personal rooms and the copossession of space enculturates a sense of continual physical connection among household member," $(1993,126)$ and goes on to support that statement with a quotation from a woman in her forties: "When you're brought up with it, I think it just makes it easier for you to share things with other people later on" (1993, 126).

The homes in Buena Vista and the way of life there display a strong connection and understanding between the people that live there. One male, John, referred to the town as "an extended family." He and his wife were attacked in their home and beaten nearly to death in the summer before I arrived. He told me that the people who attacked him were not from there because they could not be. "They wouldn't have done it if they were from here because they would be a part of the community. The community is just an extended family and you don't do that to family." The couple's survival was made possible by the efforts of the people in Buena Vista. John told me that not only did the people of Buena Vista call the police and follow the assailants until they were caught, but they followed the couple in the ambulance all the way to Ensenada and stayed in the hospital until they had come to. This person now says that they would "stick [his] hands in the fire for the people of Buena Vista because they saved [his] life." I see this persons experience and their perspective as evidence of collectivism in community. Shkodriania \& Gibbons define collectivism as:

What I experienced in Buena Vista was a family-oriented

.. Related to solidarity, concern for others, and integration with other people. Collectivistic societies emphasize the goals, needs, and views of the [collective] over those of the individual; the social norms of the [collective] as opposed to personal pleasure... cooperation instead of competition (1997, 766). 
community where everyone shared everything. There was no private space because people had nothing to hide. There was no door to my room because everything was public. At the end of it all I commented that I felt that I could be more myself than ever before; all of my social anxieties had quelled, and I believe that this is due, in great part, to the lack of privacy. Everybody saw me brush my teeth, which I did on the porch for lack of a sink. Everybody in the town saw me walk to the outhouse because it sat along the one road. Everybody who entered my house could see when I slept because there was no door and my bed was visible from the kitchen.

In retrospect, it seems so strange that it is normal to hide such behaviors that are common to all people. Pader's "Spatiality and Social Change: Domestic Space Use in Mexico and the United States" examines how the common design of U.S. homes evolved to hiding bedrooms, bathrooms, laundry rooms, and workrooms from the public eye in order to inculcate and maintain a sense of privacy. I realized that, through the normalization of privacy which forces people to hide behind the scenes, we have created, in the U.S., a culture where we leave out all common parts of our life; our family lives, our cooking, cleaning, bathing, and emoting become secrets. Because we don't acknowledge these aspects of ourselves to others, it becomes hard to recognize how these behaviors are normal and evident of the fact that, as humans, we are fundamentally the same, regardless of class, race, and national lines.

In Buena Vista, there are no washing machines or dryers, people hand wash their clothes in front of their houses and hang them up to dry outside. The whole town knows what color your underwear is and there is no shame in this. My students kept toothbrushes and cotton swabs at school and they brushed their teeth together. The feeling that I had nothing to hide, other than my taboo cigarette-smoking habit, was liberating. Towards the end, I spent less time worrying about my public performance and spent more time coexisting as a family member, as a part of the collectivist community.

\section{THE POWER OF NARRATIVE: "THEY DON'T LIKE ME EVENTHOUGHTHEY DON'T KNOW ME."}

Madan Sarup's Identity, Culture and the Postmodern World is an exploration of what our collective and individual identities represent and how they affect our interactions with the world. Sarup writes that "Public narratives become powerful myths and, even though we know how they came to be constructed, the still have a powerful force, they impel" $(1996,18)$. This quotation affirms my belief that many of the stories that we are told and the stereotypes that are agreed upon are tools to more easily organize our reality. When instead of seeing people we see assumptions, stereotypes that we project onto them, we are doing them and ourselves a great disservice by not seeing them as unique individuals, but as caricatures. After two days across the border I noted in my field journal "there have been many feelings of apprehension regarding genuine interactions with people here... In America [U.S.] it seems we are meant to see all Mexicans as being the same... and I've only met nice people! Really Nice People! Helpful and curious and genuine!" While I was aware that I was trying to fit the people I was interacting with into the pictures that the media and political theater in the U.S. had painted, the people I met were confounding this attempt by proving themselves to be unique and welcoming.

Every other weekend all of the Fort Lewis students migrated from their respective towns and met up for class in the city in the valley, Valle Hermosa, meaning "Beautiful Valley". We all stayed at a particular motel that stood on the side of the one highway that moves from the border to the southern tip of Baja. The owner of the hotel, like many people that I met in Mexico, had at some point crossed the border to find work in the U.S. Joaquin lived in San Diego for two years working as a bouncer. I expressed to him that I felt like I did not belong in Mexico, that I was an outsider; I was ashamed to be from the United States. I had assumed from the moment I had entered the country that Mexicans must hate/ resent people from the United States, and rightfully so, because of how our political and economic policies, like NAFTA (the North American Free Trade Agreement), kept wages low and working conditions abysmal. Joaquin reassured me with his perspective. "I don't hate Americans. I like to talk to people, but sometimes they don't talk to me. America tells them all the bad things to watch out for in Mexico." His face is permanently scarred from a fight he found himself in against a group of people he believed to be white supremacists in San Diego. "I don't have problems, but they don't like me even though they don't know me."

What I came to learn each time I met and spoke with a new foreign friend is exemplified by the statement that "What a passport does is to show who you are so that you can be recognized in a bureaucratic sense... it says nothing about you as a person" (Sarup 1996, XV). What Joaquin experienced was the product of people 
giving into stereotypes; people hated him, not because of who he is, but because of where he was born and the color of his skin. Sarup explores the experience of being foreign and how our identities are "not free floating; they are limited by borders" (1996, 3). My confusion and guilt were the result of being deemed a citizen of the U.S. and thus the inheritor of all the rights that are granted to anyone who holds this title.

The national identity of the United States is one of entitlement and great wealth. My very first day in Valle Hermosa, I walked along the dusty highway that the city sprawls beside. Two local males greeted and walked with me inquiring about my purpose for being there. We talked about America and one of them commented, "There is no poverty in America. Anybody can have a car there for it is the land of opportunities." This statement took me by surprise because it conveyed the common notion that people in the United States are wealthy. Of course, in comparison to the people of Mexico, U.S. citizens are very wealthy and are often afforded more material property and experiential opportunity. My ability to travel in order to come to these realizations is, in itself, proof of this fact. This national story of wealth and prosperity, through the lens of a global, capitalist culture, where to have is more important than to be, perpetuates a romanticization of the superiority of the United States. Sarup states that, "Places are created, expanded, then images are constructed to represent and sell these places" (1996, 4). I believe that this is why both U.S. citizens and Mexicans all know this same story of the United States; in order to maintain its position as a fetishized place that, in reality, is a fiction restricted by agreed upon imaginary lines.

These imaginary lines, borders, succeed in maintaining the places wherein our identities are valid. In exploring the process of forming national identities scholars suggest that a nation or a group of people must simultaneously create "other" identities against which the identity in question can be understood (Hall: 1996, Sarup: 1996, Zinn: 2003). The identity of the "other" is as much a fiction as the national identity that sparks its creation. Stuart Hall explains that, "A national culture is a discourse- a way of constructing meanings which influences and organizes both our actions and our conceptions of ourselves" (Hall 1996, 609). On one side of the line, there is wealth and prosperity while, on the other side, there are those whose poverty and disenfranchisement lays the foundation for that very wealth (Gonzales: 2011, Zinn: 2003).

BREAKING DOWN THE BORDERS BETWEEN US
When I arrived in Mexico I was looking through the eyes of a U.S. citizen, rather than a person, and I was seeing Mexicans, not family or friends or simply people. Towards the end of my time in Mexico I noted, "I and other Fort Lewis students feel as if we don't have families after experiencing what family looks like in Mexico." This auto-ethnography has been for me the first step in processing my experience in Mexico. Since returning to the U.S., I have been hypersensitive to and overwhelmed by the disconnection I see between different groups of people, as well as between U.S. citizens and the plight of the rest of the world. I believe that this disconnection between people across borders and this inability to see ourselves in others is rooted in the walls that have been put up around this nation and its particular nationalistic story. We do not need to worry about the rest of the world, only the economy and political climate here. Inspired by the Howard Zinn quotation that begins this writing, I want people to learn to recognize all people as equals. Our individual lives are inextricably connected to all other lives, be they human, animal, plant. The façade of wealth and prosperity that veils the United States does not reflect the true cost of imperial 1st world wealth. It is profound impoverishment and exploitation of those who live on the other side of the border that makes this wealth possible.

My classmates and I wondered how we would share our experiences and what we had come to learn. We wondered how we could change the social and political climate that had created the power-dynamics that uphold the structural socioeconomic inequalities we had been coming to understand as unreasonable and undeserved. We asked, "How can we make changes on individual and structural levels that would lead to an equalization of opportunity?"

We posed the idea of sending U.S. citizens to live with Mexican families, as we had done, to spark individual shifts towards empathy and a more profound understanding of the impact an average U.S. lifestyle has on the rest of the world. Yet, the very fact that we were afforded this opportunity exemplifies the power and class dynamics inherent in the current socioeconomic climate. This type of experience is a privilege that is only available to college students or people who maintain class privileges. Even the ability to cross borders with such ease is a privilege that many United States citzens take for granted. We tend not to realize that the majority of mexican citizens will not be allowed to visit the U.S. because of how stereotypes and certain narratives have 
shaped legislation and border policy. It seems contradictory for me to have gained this understanding of the supreme powers of socially-constructed socio-political narratives, only by accepting and benefiting from the privilege that these very same tales have afforded me, yet I believe there is merit to this type of experiential learning.

Experiential education by itself is not a practical approach to social justice or social change. What it does offer, however, is the opportunity to confront the physical, cultural, and ideological borders we construct and maintain that keep us isolated. In order to dissolve the power of stereotypes, on an individual level, we must carefully examine the sources and merits of our biases. This type of exploration is often most genuinely conducted when we personally interact with those people or ideas that we have prejudices against. The types of human-interactions that I experienced, combined with two college courses that contextualized the forces that were shaping the setting, led me to see through my biases and encourage me to reevaluate the roots of my behaviors and beliefs, but how can these types of interactions occur outside of these circumstances?

The context of the experiential learning must be fully recognized in order to make the social constructions visible as foundations that support social stratification. How can we destigmatize collectivity and acculturate a non-hierarchical acceptance of cultural differences? Political transformations regarding border policies, as well as economic policies such as NAFTA, policies that encourage the continued impoverishment and dehumanization of people on the grounds of their nationality, could take on and advocate for the rights of all people and a leveling of opportunity across national borders, across class lines, across gender and cultural lines. Radical revisions to the institutions that organize our social reality could find systemic practices influencing personal attitudes, just as transformations in personal attitudes can influence systemic change.

This auto-ethnography has been only one step in a process. It has benefited me by giving me a cause and forum to explore my experience and a way to communicate my story. I cannot say what, if any, benefit this project might have for the communities and my families in both Mexico and the U.S. It seems that if one person can relate to my thoughts and continue this dialogue with even one more person, then I will have sparked some positive social reflection. I wish to continue beyond my college career to raise awareness and keep asking these same questions through art, conversation, social work, and continued research. I want to understand more clearly how we maintain our identities as separate from other populations. Beyond that, I want to understand how we can break down these barriers that have been created. My goal with this project and future projects is to connect people to both individuals and whole populations whom they would likely never consider as important parts of their lives. I think that people need to talk more and listen more to people they normally would not know. I believe that this is one step towards actualizing Zinn's insightful goal of wiping out the national boundaries of the world, at least in our minds.

“IN ORDER TO DISSOLVE THE POWER OF STEREOTYPES, ON AN INDIVIDUAL LEVEL, WE MUST CAREFULLY EXAMINE THE SOURCES AND MERITS OF OUR BIASES. THIS TYPE OF EXPLORATION IS OFTEN MOST GENUINELY CONDUCTED WHEN WE PERSONALLY INTERACT WITH THOSE PEOPLE OR IDEAS THAT WE HAVE PREJUDICES AGAINST." - DE SALVO 


\section{REFERENCES}

Friere, Paulo. 1970. Pedagogy of the Oppressed. New York: The Continuum International Publishing Group Inc.

Gonzales, Juan. 2011. Harvest of Empire: A History of Latinos in America. New York: Penguin Books.

Hall, Stuart. 1996. Narrating the Nation: An Imagined Community. In Social Theory: The Multicultural and Classic Readings, edited by Charles Lemert, 609-615. 4th ed. Boulder, C0: Westview.

Pader, Ellen. 1993. "Spatiality and Social Change: Domestic Space Use in Mexico and the United States." American Ethnologist 20.1: 114-137.

Sarup, Madan. 1996. Identity, Culture, and the PostModern World. Athens: University of Georgia Press.

Shkodriani, Gina. and Gibbons, Judith. 1995. “Individualism and Collectivism Among University Students in Mexico and the United States." The Journal of Social Psychology 135.6: 765-772.

Zinn, Howard. 2003. A People's History of the United States: 1492-present. New York: HarperCollins.

This work is licensed under a Creative Commons AttributionNonCommercial-

NoDerivs 3.0 Unported License. 